\title{
EFFECTS OF VALPROATE AND FLUOXETINE COMBINATION ON YMRS AND MADRS SCORES IN CONTINUATION PHASE TREATMENT OF BIPOLAR DISORDER
}

\author{
Ganesha T Trengginas ${ }^{1}$, Didik Hasmono ${ }^{1}$, Roni Subagyo ${ }^{2}$ \\ ${ }^{1}$ Faculty of Pharmacy, Universitas Airlangga, Surabaya, ${ }^{2}$ Department of Psychiatry, Bhayangkara Hospital, Kediri, \\ Indonesia
}

\section{ABSTRACT}

\begin{abstract}
Valproate is the most common drug to use in bipolar disorder in Indonesia and the only mood stabilizer drug in national formu lary. Combination of valproate and fluoxetine is the mostly used combination in bipolar disorder therapy in Bhayangkara Hospital, Kediri. However, this combination has been controversial because of its risk of triggering mania or hypomania episode in 12 months. The aim of this study was to analyze mood change symptoms with YMRS and MADRS scale after treatment of valproate and fluoxetine combination in continuation phase treatment of bipolar disorder. This cross-sectional, observational study was conducted in psychiatry clinic in Bhayangkara Hospital Kediri between August 2016-October 2016 on 15 patients in YMRS. MADRS questionnaire was filled by physician before and after 8 weeks of the treatments. Within 8 weeks, mean YMRS score changed from 1.4 to 1.26 ( $p>0.05)$. Whereas, mean MADRS score changed from 31.8 to 10.93 ( $p<0.05)$. There was no significant difference in YMRS score between pre-and post-treatment, but there was significant difference in MADRS score after treatment.
\end{abstract}

Keywords: Bipolar disorder; valproate; fluoxetine; YMRS; MADRS

\section{ABSTRAK}

Valproate adalah pilihan obat paling banyak dalam gangguan bipolar yang digunakan di Indonesia dan satu-satunya obat penstabil mood yang tersedia di formularium nasional. Kombinasi valproate dan fluoxetine adalah kombinasi yang paling sering digunakan dalam terapi gangguan bipolar di Rumah Sakit Bhayangkara Kediri. Namun, kombinasi ini telah kontrovesial karena risikonya memicu episode mania atau hipomania dalam 12 bulan. Tujuan dari penelitian ini adalah untuk menganalisis gejala perubahan suasana hati dengan skala YMRS dan MADRS setelah pengobatan kombinasi valproate dan fluoxetine dalam perawatan fase lanjutan gangguan bipolar. Penelitian observasional cross-sectional ini dilakukan di klinik psikiatri di Rumah Sakit Bhayangkara Kediri antara Agustus 2016 - Oktober 2016 pada 15 pasien di YMRS. Kuesioner MADRS diisi oleh dokter sebelum perawatan dan setelah 8 minggu perawatan. Dalam 8 minggu, skor rata-rata YMRS berubah dari 1,4 menjadi 1,26 ( $p>0,05)$. Sedangkan rataan skor MADRS berubah dari 31,8 menjadi 10,93 ( $<$ <0,05) setelah 8 minggu. Tidak ada perbedaan yang signifikan dalam skor YMRS antara pra perawatan dan pasca perawatan, tetapi ada perbedaan yang signifikan dalam skor MADRS setelah perawatan.

Kata kunci: Gangguan bipolar; valproate; fluoxetine; YMRS; MADRS

Correspondence: Ganesha T. Trengginas, Faculty of Pharmacy, Universitas Airlangga, Jalan Dharmawangsa Dalam Surabaya 60286, Indonesia. E-mail: ganeshatrengginas@gmail.com

pISSN:2355-8393 • eISSN: 2599-056x • doi: http://dx.doi.org/10.20473/fmi.v54i4.10704

- Fol Med Indones. 2018;54:234-240 • Received 1 Mar 2017 • Accepted 21 Sep 2017

- Open access under CC-BY-NC-SA license • Available at https://e-journal.unair.ac.id/FMI/

\section{INTRODUCTION}

Bipolar disorder is number 2 most studied psychiatric disorder after schizophrenia and becomes one of disability cause that is related to morbidity and mortality (Raza et al 2016). According to WHO survey report in 2000 , bipolar disorder accounted for $0.49 \%$ of global burden disease, with $2.5 \%$ of total YLD (Year Lived Disability) (WHO 2001).

Therapy used in bipolar affective disorder is mood stabilizer. Medications that are commonly used include lithium, valproate, oxcarbazepine, carbamazepine, and lamotrigine (Reus 2015). Therapy on this disorder is divided into 3 phases, i.e. acute phase, continuation phase, and maintenance phase. In the acute phase, drug therapies aim at stabilization, early control and the prevention of more severe manifestations. On the continuation phase, drug therapy is intended to achieve remission. Whereas, on the maintenance phase, drug therapy is used to maintain a condition of remission. In addition to the use of a mood stabilizer, antidepressants can be used in patients with severe depression, though its use is still controversial, and is not recommended as 
the sole therapy on episodes of depression disorders (Corryell 2013).

To perform an initial assessment and measuring the success of the initial treatment, different quantitative instrument episode is dominant depending on the patient. Episode of depression rate is measured using standard instruments filled by clinicians with Hamilton Depression Rating Scale (HDRS) and MontgomeryAsberg Depression Rating Scale (MADRS), or instrument which is filled by the patients, such as the Patient Health Questionnaire-9 (DeBattista et al 2015). As for the episodes of mania, YMRS (Young Mania Rating Scale) and CGI-BP (Clinical Global Impression Bipolar) instruments are used, filled by clinicians. YMRS instrument focuses on the symptoms experienced by the patients during the examination, while CGI-BP focuses on the assessment of disease severity. Assessment outcomes may also be associated with remission rate or recurrence rate (Lukasiewicz et al 2013, Moosavi et al 2014).

Valproate is one of bipolar affective disorder therapy that is widely used in Indonesia and has been entered into a national formulary. Valproate is an anti-seizure drug that has the effect of mood stabilizers, works by inhibiting the depolarization of neurons and inhibits enzymes that degrade GABA (Brunton et al 2010). Valproate has good oral absorption. Its wide distribution volume is $11 \mathrm{~L} / 1.73 \mathrm{~m}^{2}$ because it is quite lipophilic and strongly bound in the plasma proteins by $80-90 \%$. Its weakness is due to its metabolism which is highly dependent on the liver and glucuronic conjugation process. It may interfere with other drugs metabolized by same subtype cytochrome as well as the non-linear kinetics (Lacy et al 2009). Over the past 15 years, valproate has been used in the treatment of psychiatric disorders as a mood stabilizer in acute mania disorder and bipolar disorder (Ghaleiha et al 2014).

However, approximately $20-40 \%$ of patients using valproate therapy show less response or insufficiency. For patients in the acute phase, the therapy in patients who are less responsive to valproate loading dose can be conducted at the beginning or increasing doses at regular intervals (Ghaleiha et al 2014). Patients with advanced stages, patients with recurrent symptoms during treatment or refractory patients are subjected to medication replacement, or in the addition of other drugs, such as carbamazepin, lithium, or SSRI antidepressant drugs and antipsychotics (Gajwani 2009). The combined use of mood stabilizers in advanced phase bipolar disorder can reduce relapse rates within a period of 2 years, but the use of more than two drugs cannot provide a significant increase in the number of relapses (Peselow et al 2016).
The combined use of drugs is a strategy that is often used in patients who do not respond well to therapy of single valproate. In Bhayangkara Hospital Kediri, a combination of the most widely used drugs is the antidepressants class of SSRI, which is fluoxetine, although until now the combination of mood stabilizers with antidepressants in the advanced phase or long-term therapy is controversial because some studies mention that there is a risk of 4 to $44 \%$ to trigger episodes of mania or hypomania (Gijsman et al 2004, Truman et al 2007). Therefore, this study was conducted in order to identify the effect of the combined use of valproate and fluoxetine on the symptoms of mood disorders measured using YMRS and MADRS scores in patients with advanced phase of bipolar disorder.

\section{MATERIALS AND METHODS}

This cross-sectional, observational study was conducted on 15 patients in psychiatry clinic in Bhayangkara Hospital, Kediri from August 2016 to October 2016. YMRS and MADRS questionnaires were filled by physician before and after 8 week of the treatment.

This study was conducted in order to identify the effect of the combined use of valproate and fluoxetine on mood status, measured using YMRS and MADRS scores in patients with bipolar disorder during the continuation phase of 8 week observation of outpatient. The study was conducted by observing YMRS and MADRS scores before treatment and after treatment. In this study all patients received the same doses of valproate $(2 \times 250 \mathrm{mg})$ and fluoxetine $(1 \times 20 \mathrm{mg})$. The observation was conducted from August to December 2016. The number of patients who met the inclusion criteria was 18 patients. A total of 3 patients expressed dropout because they could not tolerate the side effects of drugs, so that the number of patients being considered in the analysis were 15 patients. This study also observed patients who took valproate monotherapy, ie 2 x $250 \mathrm{mg}$ by 2 patients. However, because the number of patients was too small, it could not be used as a benchmark to measure the effectiveness.

\section{RESULTS}

This study was conducted to determine the effect of valproate combination therapy and fluoxetine to changes in mood characterized by changing Young Mania Rating Scale (YMRS) score and MontgomeryAsberg Depression Rating Scale (MADRS) score. This research was conducted in Bhayangkara Hospital, Kediri by taking bipolar affective disorder patients who visited the continuation phase psychiatry clinic from 
August to October 2016, The subjects were then observed for their changes in YMRS and MADRS scores after 8 weeks of therapy. All the patients obtained the same drug and dosage, which were $2 \times 250$ $\mathrm{mg}$ valproate and 1 × $20 \mathrm{mg}$ fluoxetine 1 × 20 . The number of patients who met the inclusion criteria were 18 patients. A total of 3 patients dropped out during the study due to the side effects of drugs that could not be tolerated by the patients. Thus, the number of patients that could be analyzed were 15 patients. Sample characteristics, including gender, age, occupation (daily routine activities), and medication adherence of the patients are presented in Table 1.

During the study, the assessments of the changes in symptoms of mania with the questionnaire Young Mania Rating Scale (YMRS) and the change in symptoms of depression with the Montgomery-Asberg Depression Rating Scale (MADRS) were carried out. The assessments were done 2 times, before and after treatment.

\section{DISCUSSION}

To analyze the effect of specific symptom decrease in the disease course, an analysis of the value of each aspect of the question in the questionnaire YMRS and MADRS in all patients was performed. In YMRS questionnaire, only one aspect of the question which could be analyzed. For other aspects, the value was 0 or unobservable. This was because the symptoms of depressive episodes were more dominant than manic symptoms. Thus, manic symptoms could not be observed.

Table 1. Characteristics of subjects

\begin{tabular}{|c|c|c|c|}
\hline \multirow{2}{*}{ Characteristics of Subjects } & \multicolumn{2}{|c|}{ Samples } & \multirow[b]{2}{*}{$\mathrm{p}$} \\
\hline & Total & $\%$ & \\
\hline \multicolumn{4}{|l|}{ Gender } \\
\hline Male & 3 & 20.00 & \multirow{2}{*}{0.000} \\
\hline Female & 12 & 80.00 & \\
\hline Age (Years) & \multicolumn{2}{|c|}{$\begin{array}{c}40.60 \pm 3.35 \\
(18.00-58.00)\end{array}$} & 0.36 \\
\hline \multicolumn{4}{|l|}{ Employment (Daily Activities) } \\
\hline Government employees & 4 & 26.67 & \\
\hline Entrepreneurial & 3 & 20.00 & \\
\hline Student & 2 & 13.33 & \\
\hline Housewife & 6 & 40.00 & \\
\hline \multicolumn{4}{|l|}{ Drug Compliance } \\
\hline Compliance & 11 & 73.33 & \multirow{2}{*}{0.000} \\
\hline Disobedient & 4 & 26.67 & \\
\hline
\end{tabular}

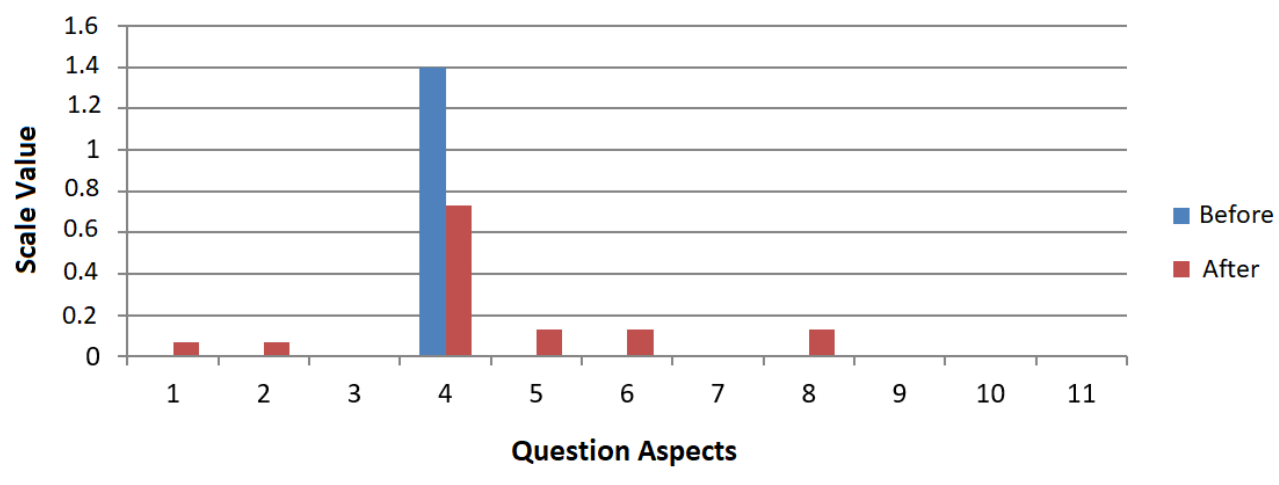

Fig. 1. Ratings on every aspect of the YMRS questionnaire. Description: Aspect $1=$ Increased natural feeling; Aspect 2 = Increased motor activity; Aspect $3=$ sexual interest; Aspect $4=$ Sleep; Aspect $5=$ Irritability; Aspect $6=$ Discussion (speed and number); Aspect $7=$ Language-obsession; Aspect $8=$ Fill thought; Aspect $9=$ Aggressive behavior-bother; Aspect $10=$ Appearance; Aspect $11=$ insight . 


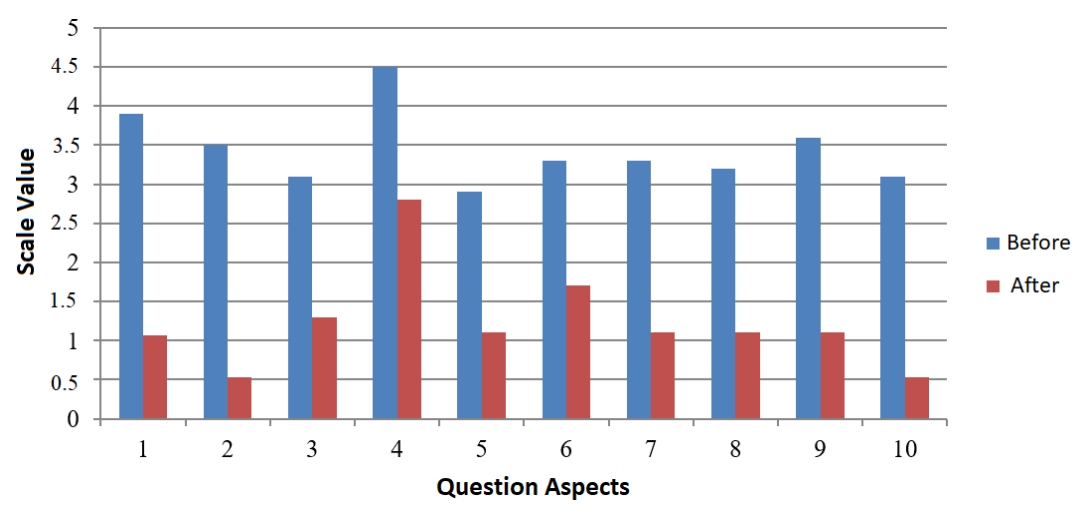

Fig. 2. Ratings on every aspect of the MADRS questionnaire. Description: Aspect $1=$ sadness seemed; Aspect $2=$ Grief reported; $3=$ Tension inner aspect; Aspect $4=$ Reduced sleep; Aspect $5=$ Decreased appetite; Aspect $6=$ Difficulty of concentration; Aspect $7=$ Weakness; Aspect $8=$ Inability to feel; Aspect $9=$ Thoughts pessimistic; Aspect $10=$ Thoughts of suicide.

Table 2. Assessment Young Mania Rating Scale (YMRS) and Montgomery-Asberg Depression Rating Scale (MADRS) on samples

\begin{tabular}{lcccccc}
\hline \multicolumn{1}{c}{ Mean } & Median & SD & Min & Max & Shapiro-Wilk (p) \\
\hline Baseline & & & & & & \\
$\quad$ YMRS & 1.40 & 1.00 & 0.16 & 0.00 & 2.00 & $0.001^{* *}$ \\
$\quad$ MADRS & 31.80 & 34.00 & 1.67 & 20.00 & 42.00 & 0.47 \\
End point & & & & & & \\
$\quad$ YMRS & 1.27 & 1.00 & 0.56 & 0.00 & 9.00 & $0.00^{* *}$ \\
$\quad$ MADRS & 10.93 & 12.00 & 1.73 & 2.00 & 24.00 & 0.46 \\
Changes during observation & & & & & \\
$\quad$ YMRS & 1.07 & 0.00 & 0.47 & 0.00 & 7.00 & $0.00^{* *}$ \\
$\quad$ MADRS & 20.87 & 19.00 & 2.31 & 10.00 & 36.00 & 0.16 \\
\hline \multicolumn{2}{l}{ Note: **Significant $(\mathrm{p}<0.05)$} & & & & &
\end{tabular}

Table 3. Wilcoxon signed rank test on YMRS score

\begin{tabular}{lccccc}
\hline & Mean & SD & Min & Max & $p$ \\
\hline YMRS score & & & & & \\
Baseline & 1.40 & 0.63 & 0.00 & 2.00 & $0.23^{*}$ \\
End point & 1.26 & 2.19 & 0.00 & 9.00 & \\
\hline Note: *insignificant & $(\mathrm{p}>0.05$; Wilcoxon signed rank test)
\end{tabular}

Table 4. Paired t-test on MADRS score

\begin{tabular}{cccccc}
\hline & Mean & SD & Min & Max & p \\
\hline MADRS score & & & & & \\
Baseline & 31.80 & 6.46 & 20.00 & 42.00 & $0.00^{* * *}$ \\
End point & 10.93 & 6.71 & 2.00 & 24.00 & \\
\hline
\end{tabular}

To analyze the effect of depression symptom decrease, an analysis on every aspect of the question based on MADRS questionnaire was performed. The results showed that a combination of valproare and fluoxetine can improve aspects of visible sadness, reported sadness, inner tension, decreased sleep time, decreased appetite, concentration difficulties, weakness (activity), inability to feel (mood), pessimistic thoughts, and suicidal. However, when viewed from the mean decrea- se value in symptoms of depression before and after treatment, the biggest decrease occurred in the aspect of reported sadness of 2.9 points. Whereas, in the aspect of visible sadness, there was a decrease of 2.8 points. The lowest decrease in mean value occurred in the aspect of sleeping and concentraton difficulties as much as 1.6 points. The magnitude of the decrease depended on the initial sample, in which the aspects of reported and 
visible sadness had higher initial value, which were 3.9 and 3.5 points.

Valproate is a mood stabilizer that works by inhibiting the depolarization of neurons and inhibit enzymes that degrade GABA (Lacy et al 2009). Whereas, fluoxetine from the SSRI class (Selective Serotonin Reuptake Inhibitor) is a drug that works with 5-HT1A, 5-HT1D, 5-HT7 selective inhibitory receptors. Wherein these receptors are receptors that are inhibited in the task of re-uptaking intracellular serotonin so as to increase serotonin levels (Brunton et al 2010). The molecular mechanism of the two drugs is associated with specific effects of symptom improvement after administration of drug combinations. In the use of valproate, the expected positive effect of inhibitory neuron depolarization and increased GABA activity is increased sleep patterns and prevention of anxiety (Widmaier et al 2014). Whereas, the use of fluoxetine is expected to increase serotonin that can improve the situation in general mood, aggression, memory, sleep, appetite, and willingness to socialize (Pytliak et al 2011).

To determine the uniformity value at baseline YMRS and MADRS patients, the final value of observation and changes in value during the observation, we carried out Shapiro-Wilk normality test. At the baseline YMRS, the analysis of normality with the Shapiro-Wilk test showed the probability $(\mathrm{p})$ of $0.001 \quad(\mathrm{p}<0.05)$. Whereas, the analysis of observations using YMRS on the final value of normality showed probability $(p)$ of $0.00(p<0.05)$. The normality test on the difference between the baseline and end point of YMRS observation value showed probability $(\mathrm{p})$ of $0.00(\mathrm{p}<0.05)$. Therefore, the results of the normality test in all three showed that the results were not normally distributed (the third normality test showed p-value less than 0.05). Furthermore, the Wilcoxon signed rank of nonparametric test was used to identify the results of the mean YMRS score.

As for the normality test score of MADRS, ShapiroWilk test showed probability $(p)$ of $0.47(p>0.05)$. For analysis of the end point value of normality, MADRS showed observation probability $(p)$ of $0.46(p>0.05)$. Whereas, the normality test on the difference between the baseline and the end point of the MADRS observation value showed probability $(p)$ of $0.16(p>0.05)$. The results of the normality test of the three showed that the results were not normally distributed (the third normality test showed $\mathrm{p}$ value higher than 0.05 ). Therefore, the MADRS score analysis was conducted with parametric paired t test.

To measure changes in symptoms of mania in patients, the instrument of Young Mania Rating Scale (YMRS) was used. YMRS instrument is a questionnaire with 11 questions with scoring system for each answer choice. YMRS value ranges from 0 to 60 . YMRS instrument was completely filled by the clinician responsible for the direct interview method with the patients or the patients' family. Table 3 shows that in the analysis of the combination therapy of valproate and fluoxetine effects on YMRS score during the study, the results of the Wilcoxon rank test show significant value of 0.23 $(>0.05)$. This means that the results of the comparison between mean baseline and end point score does not show a significant difference. According to Grunze et al (2018), the criteria for YMRS remission instruments are 12 (Grunze et al 2018), whereas when observed from the data, mean YMRS baseline was 1.4 and in end point value was 1.26 with the highest values of 2.0 and 9.0 respectively. It can be concluded that as long as all observations of patients were in remission status, improvement in manic symptoms was no longer significant (1 patient was found to appear with dominant symptoms of mania which were declared discontinued due to side effects of the drug).

To measure changes in depressive symptoms in the patients, the Montgomery-Asberg Depression Rating Scale (MADRS) instrument was used. The MADRS instrument consists of 10 questions with each question having a value of 0 to 6 . The values in the MADRS instrument range from 0 to 60 , and were filled in completely by the doctor responsible for the interview method directly to the patients or the patients' family. Table 4 shows the results of the effects of the combination therapy of valproate and fluoxetine on the MADRS score with the paired t-test showing a significance value of 0.00 $(<0.05)$. This means that the results of the comparison between the initial and final means of the MADRS from the observations did not show a significant difference. According to Grunze et al (2018), the remission limit value of MADRS is 10 . When observed from baseline and end point of treatment, the average MADRS at baseline was 31.8 and the final result of observation was 10.93. Only 7 out of 15 patients $(46.7 \%)$ had remission criteria for the MADRS with a score of 10 . For patients who had not reached the MADRS target, the remission criteria needed to be confirmed again if replacement drugs were needed or for patients who showed good progress with a combination of fluoxetine from valproate, and it continued until the drug reached remission.

In the MADRS score analysis, there were two patients who showed higher final MADRS scores, namely the patients number 8 and 15. Patient 8 had a pre-therapy score of 36 and the value after therapy was 22 . When decomposed on each aspect of the question in the patients, there was no improvements in the aspects of visible sadness, reported sadness, inner tension and lack 
of sleep. From the doctor's decision, the patient continued the combination therapy of valproate and fluoxetine because of qualitative improvement (in interview of doctor visit). For this patient, supervision over a longer period of time to assess whether a replacement was needed was to be done. The pathogenesis of bipolar disorder was unclear and there was involvement of many neurotransmitters, inflammatory markers, and changes in brain structure that caused individual drug responses to be difficult to predict and very unique from each individual. Therefore, the treatment of each patient was very individual and can change at any time if there was a change in symptoms (Raza et al 2016).

Patient number 15 was known to have non-compliance for taking medication. The patient did not take medicine at the eighth week. From the results of the interview it was revealed that the patient felt good so he did not take medication and returned his appointment to the psychiatric clinic. Valpraote is classified as a mood stabilizer that has pharmacokinetic characteristics which is advantageous because it can last longer in the body by achieving a rapid peak level of 4 hours (Lacy et al 2009). However, the use of valproate is highly dependent on liver function, therefore it is necessary to monitor liver function and other drugs that can induce or inhibit enzymes in the liver. Fluoxetine has beneficial pharmacokinetic characteristics where the half-life is very long up to 4-6 days in long-term use. The fluoxetine metabolite, norfluoxetine, has a half-life of 9.3 days and has activities similar to fluoxetine. This is also a benefit of using fluoxetine (Lacy et al 2009). With this characteristic, when patients miss one dose of the drug, pharmacokinetics is not a problem. However, that will be a problem if the patient does not take the drug during the first week. In addition, both have a wide and very individual dose range (valproate $250 \mathrm{mg}$ to $1000 \mathrm{mg}$ per day and fluoxetine $10-40 \mathrm{mg}$ or $90 \mathrm{mg}$ per week [Lacy et al 2009]), so that the possibility of doses taken by the patient is sufficient to maintain or improve mood. However, still not receiving therapy is dangerous for the patients because it can cause loss of control over the course of the patient's disease and can cause relapse. Therefore, good counseling to understand the disease and the importance of therapy is very important for the patients, especially in those who have a greater tendency for psychiatric disobedience. Therapy for mood disorders depends not only on drug therapy, but also on the patient and the patient counseling which also makes environmental changes that affect treatment outcomes.

The use of fluoxetine in bipolar disorder, especially in the advanced phase, is controversial because of the reports on the incidence of mania episodes or hypomania during drug use (Gijsman et al 2004, Truman et al 2007). This was not reported in this study. A total of 15 patients analyzed did not experience episodes of mania or hypomania during treatment in continuation phase.

\section{CONCLUSION}

Valproate and fluoxetine combination therapy can maintain remission in symptoms of mania as measured using Young Mania Rating Scale (YMRS) questionnaire. Combination therapy of valproate and fluoxetine can improve the symptoms of depression in the aspects of visible sadness, reported sadness, inner tension, decreased sleeping time, decreased appetite, difficulty of concentrating, weakness (activity), inability to feel (the atmosphere), pessimistic thoughts, and suicidal thoughts which were measured using Montgomery-Asberg Depression Rating Scale (MADRS) questionnaire.

\section{REFERENCES}

Brunton LL, Chabner BA, dan Knollmann BC (2010). Goodman and Gilman's The Pharmacological Basis of Therapeutics. 12th ed, p 397-414

Corryell W (2013). Bipolar Disorders. Merck Manual Professional. Available from http://www.merckmanuals.com/professional/psychiatric-disorders/mood-disorders/bipolar-disorders

DeBattista C, Eisendrath SJ, Lichtmacher JE (2015). Mood Disorder. Psychiatric Disorders. In: CURRENT Medical Diagnosis and Treatment 44th Edition. USA, McGraw-Hill, p 1051-1053

Gajwani P (2009). Treatment-refractory bipolar disorder: classification to aid in clinical management. Expert Opinion on Pharmacotherapy 10, 1907-1915

Ghaleiha A, Haghighi M, Sharifmehr M, et al (2014). Oral loading of sodium valproate compared to intravenous loading and oral maintenance in acutely manic bipolar patients. Neuropsychobiology 70, 29-35

Gijsman HJ, Geddes JR, Rendell JM, et al (2004). Antidepressants for bipolar depression: A systematic review of randomized, controlled trials. Am J Psychiatry $161,1537-1547$

Grunze H, Vieta E, Goodwin GM, et al (2018). The World Federation of Societies of Biological Psychiatry (WFSBP) Guidelines for the Biological Treatment of Bipolar Disorders: Update 2012 on the longterm treatment of bipolar disorder. The World Journal of Biological Psychiatry 14, 154-219

Lacy CF, Amstrong LL, Goldman, NP, et al (2009). Drug Information Handbook. 18th ed. AphA, LexiComp

Lukasiewicz M, Gerard S, Besnard A, et al (2013). Young Mania Rating Scale: how to interpret the 
numbers? Determinationof a severity threshold and of the minimal clinically significant difference in the EMBLEM cohort. Int. J. Methods Psychiatr. Res 22, 46-58

Moosavi SM, Ahmadi M, Monajemi MB (2014). Risperidone versus risperidone plussodium valproate for treatment of bipolar disorders: A randomized, doubleblind clinical-trial. Global Journal of Health Science 6

Peselow ED, Naghdechi L, Pizano D, IsHak WW (2016). Polypharmacy in maintenance of bipolar disorder. Clinical Neuropharmacology 39, 132-134

Pytliak M, Vargova V, Mechirova V, et al (2011). Serotonin receptors-from molecular biology to clinical applications. Physiol. Res 60, 15-25
Raza MU, Tufan T, Wang Y, Hill C, Zhu MY (2016). DNA damage in major psychiatric diseases. Neurotox Res 30, 251-257

Reus VI (2015). Mental disorder. In: Harrison's Principles of Internal Medicine. 19th Ed. USA, McGrawHill, p 2717-2719

Truman CJ, Goldberg JF, Ghaemi SN et al (2007). Selfreported history of manic/hypomanic switch associated with antidepressant use: data from the Systematic Treatment Enhancement Program for Bipolar Disorder (STEP-BD). J Clin Psychiatry 68, 1472-9

WHO (2001). Global Burden of Disease 2000 Study. World Health Report

Widmaier EP, Raff H, Strang KT (2014). Vander's Human Physiology: Mechanism of Body Function. 13th Ed, p 167-172 